\title{
Застосування контактного охолодження повітря аеротермопресором в циклі газотурбінної установки
}

\section{Д. В. Коновалов ${ }^{\bowtie}$ Г. О. Кобалава}

Херсонська філія Національного університету кораблебудування імені адмірала Макарова, пр. Ушакова, 44, м. Херсон, 73003, Україна

$\triangle$ e-mail: dimitriyko79@gmail.com

\begin{abstract}
Проведено аналіз існуючих газотурбінних установок (ГТУ) із застосуванням проміжного охолодження циклового повітря різних фірм-виробників, визначені основні технічні характеристики та головні параметри роботи иих ГТУ. Розглянуто основні шляхи реалізації проміжного охолодження циклового повітря ГТУ, а саме охолодження в поверхневому теплообміннику та контактне охолодження при упорскуванні диспергованої води. Перспективним способом зволоження робочого середовища ГТУ може бути застосування аеротермопресорного апарату, в основу роботи якого покладено прочес термогазодинамічної компресії (термопресії). Особливістю ичього процесу є підвищення тиску в результаті миттєвого випаровування рідини, щзо упорскується в повітряний потік, який прискорений до швидкості близько звуковій. При иьому на випаровування води відводиться теплота від газу, в результаті чого знижується його температура. В роботі проведено порівняльний аналіз існуючих та аеротермопресорних технологій для проміжного охолодження повітря ГТУ. Виявлено, щзо аеротермопресор дозволяє підвищити тиск ииклового повітря між ступенями компресора на 2 ...9 \%, щзо призводить до зменшення роботи на стиснення в ступенях компресора, а упорскування води, відповідно, до збільшення кількості робочого тіла в цииклі на $2 \ldots 5 \%$, $і$, як наслідок, збільшується питома потужність на $3 \ldots 10 \%$ та ККД ГТУ на $2 \ldots 4 \%$.
\end{abstract}

Ключові слова: Аеротермопресор, Газотурбінні установки, Проміжне охолодження, Питома витрата палива

\section{1. Вступ}

В сучасних умовах розвитку енергетики в Україні та Світі вкрай актуальним є впровадження високоефективних енергогенеруючих установок. Перспективним $\epsilon$ застосування, як в стаціонарній, так і в транспортній енергетиці, газотурбінних установок (ГТУ).

Сучасним ГТУ притаманні такі переваги: невеликі масогабаритні показники та компактність; швидкість запуску, висока маневреність; модульність і простота конструкції допоміжних механізмів і систем; надійність; великі потенційні можливості щодо подальшого підвищення енергетичної ефективності та інших показників.

\section{2. Аналіз проблеми і постановка мети дослі- дження}

Для підвищення енергетичної ефективності ГТУ широко застосовувалися цикли з регенерацією теплоти відхідних газів. Однак, розвиток ГТУ на базі конверсійних двигунів призвело до витіснення ГТУ з регенерацією.

Конверсійні ГТУ мають високу ступінь підвищення тиску в компресорі. Це сприяє зменшенню маси і габаритів установки, однак, в той же час, зменшує ефективність застосування регенерації теплоти відхідних газів для підвищення енергетичної ефективності ГТУ в цілому [1].

Одним 3 ефективних способів підвищення ефективності ГТУ $є$ застосування проміжного охолодження циклового повітря при стисненні і проміжного підігріву газів при розширенні (дворазове підведення теплоти) [2]. У свою чергу, це дозволяє застосовувати цикл 3 регенерацію теплоти відхідних газів в ГТУ з високим ступенем підвищення тиску в компресорах.

Проміжне охолодження циклового повітря установки можливо здійснювати двома шляхами: охолодження в поверхневому теплообміннику [3] або контактне охолодження при упорскуванні диспергованої води [1].

Сучасним та розповсюдженим шляхом підвищення показників ГТУ $\epsilon$ зволоження робочого середовища (циклового повітря). Для цього застосовується упорскування води [1]:

1) перед компресором;

2) в компресор при стисненні (проміжне між ступенями компресора);

3) упорскування пари в камеру згоряння;

4) упорскування пари в продукти згоряння перед турбіною.

Упорскування води перед компресором або між ступенями компресора, як правило, застосовується для підвищення потужності та економічності ГТУ при високих температурах зовнішнього повітря. Упорскування пари, що генерується в утилізаційних тепловикорис- 
товуючих контурах, підвищує потужність і економічність ГТУ за рахунок збільшення кількості робочого тіла в циклі.

Перспективним способом зволоження робочого середовища ГТУ може бути застосування аеротермопресорного апарату (аеротермопресора) [4]. В основу роботи аеротермопресора покладено процес термогазодинамічної компресії (термопресії). Особливістю цього процесу є підвищення тиску в результаті миттєвого випаровування рідини, що упорскується в повітряний потік, який прискорений до швидкості близько звуковій. При цьому на випаровування води відводиться теплота від газу, в результаті чого знижується його температура [5].

До переваг застосування аеротермопресора слід віднести наступне: підвищення тиску та охолодження робочого середовища дозволить зменшити роботу на стиснення в компресорі ГТУ; забезпечить ефективне розпилення і зволоження рідини (води) між ступенями компресора, що, у свою чергу, дозволить зменшити додатково роботу компресора при випаровуванні крапель води в проточній частині при стиснені, а також дозволить збільшити кількість робочого тіла в циклі.

Мета дослідження - аналіз ефективності застосування контактного охолодження і зволоження повітря аеротермопресором в циклі ГТУ.

\section{3. Результати дослідження}

Серед розглянутих технологій проміжного охолодження циклового повітря ГТУ представлені дані таких відомих фірм-виробників, як Rolls-Royce, General Electric та BAT "Невський завод" (табл. 1).

В газотурбінному агрегаті (ГTA) WR-21 фірми Rolls Royce 3 метою підвищення ефективності застосовані сумісне проміжне охолодження повітря між компресорами та регенерація теплоти відпрацьованих газів. При значеннях ступеню підвищення тиску повітря у компpecopax $\pi_{\mathrm{K}}=16,2$, питома витрата палива склала $g_{\mathrm{e}}=$ $=0,190$ кг/кВт год та ККД $-\eta_{\mathrm{e}}=41,2 \%[6,7]$. У 2005 р. General Electric запровадила в промислову експлуатацію газову турбіну LMS100 номінальною потужністю майже 100 МВт з використанням технології проміжного охолодження повітря між компресорами. Ця ГТУ забезпечує на сьогодні найвищий ККД у відкритому циклі. Особливість LMS100 полягає у використанні проміжного охолодження в межах секції стиснення повітря в компресорі. Сьогодні це єдиний у світі серійно виготовлюваний агрегат подібного типу. Застосування проміжного охолодження в LMS100 дозволило збільшити ступінь підвищення тиску повітря до $\pi_{\mathrm{\kappa}}=40$, i початкову температуру газу $\mathrm{T}_{\mathrm{r} 1}=1653 \mathrm{~K}$ при цьому ККД склало $\eta_{\mathrm{e}}=45,5 \%$ [8].

Таблиця 1 - Основні технічні характеристики ГТУ з проміжним охолодженням повітря.

\begin{tabular}{|c|c|c|c|c|}
\hline Параметри ГТУ & WR-21 & LMS 100 & LM6000-PC SPRINT & "Надія" \\
\hline Фірма-виробник & $\begin{array}{c}\text { "Rolls Royce } \\
\text { plc","Westinghouse } \\
\text { Electric Corp.", } \\
\text { Великобританія }\end{array}$ & $\begin{array}{l}\text { "General Electric } \\
\text { Company", США }\end{array}$ & $\begin{array}{l}\text { "General Electric } \\
\text { Company", США }\end{array}$ & $\begin{array}{c}\text { ВАТ "Невский завод", } \\
\text { Росія }\end{array}$ \\
\hline $\begin{array}{l}\text { Спосіб охолодження } \\
\text { циклового повітря }\end{array}$ & $\begin{array}{c}3 \text { поверхневим пові- } \\
\text { троохолоджувачем } \\
\text { та рекуператором }\end{array}$ & $\begin{array}{c}3 \text { поверхневим } \\
\text { повітроохоло- } \\
\text { джувачем }\end{array}$ & $\begin{array}{c}3 \text { контактним охоло- } \\
\text { дженням }\end{array}$ & $\begin{array}{c}3 \text { поверхневим повіт- } \\
\text { роохолоджувачем та } \\
\text { рекуператором }\end{array}$ \\
\hline Місце експлуатації & $\begin{array}{c}\text { ВМФ США, на ко- } \\
\text { раблях }\end{array}$ & $\begin{array}{c}\text { Стаціонарна } \\
\text { установка }\end{array}$ & $\begin{array}{c}\text { Стаціонарна } \\
\text { установка }\end{array}$ & $\begin{array}{c}\text { Стаціонарна } \\
\text { установка }\end{array}$ \\
\hline $\begin{array}{l}\text { Потужність } \\
N_{\mathrm{e}}(\mathrm{ISO}), \text { кВт }\end{array}$ & 25250 & 98600 & 46800 & 16300 \\
\hline $\begin{array}{l}\text { Питома витрата палива } \\
g_{\text {e, }} \text { кг/кВт·год }\end{array}$ & 0,190 & 0,158 & 0,171 & 0,163 \\
\hline КПД $\eta_{\mathrm{e}}, \%$ & 41,2 & 45,5 & 41,8 & 42,1 \\
\hline $\begin{array}{l}\text { Ступінь підвищення } \\
\text { тиску } \pi_{\kappa}\end{array}$ & 16,2 & 40 & 30,5 & 9,55 \\
\hline $\begin{array}{l}\text { Витрата повітря } \\
G_{\text {п }}, \text { кг/с }\end{array}$ & 73,0 & 204,0 & 133,0 & 58,5 \\
\hline $\begin{array}{l}\text { Температура газу перед } \\
\text { турбіною } T_{\mathrm{T} 2}, \mathrm{~K}\end{array}$ & 1255 & 1653 & 1244 & 1100 \\
\hline $\begin{array}{l}\text { Температура газу на } \\
\text { виході } T_{\text {вих }}, \mathrm{K}\end{array}$ & 628 & 689 & 714 & 415 \\
\hline $\begin{array}{l}\text { Частота обертання си- } \\
\text { лової турбіни, об/хв }\end{array}$ & 3600 & 3600 & 3600 & 5500 \\
\hline Maca, T & 54,4 & н/д & 204,0 & 42,0 \\
\hline
\end{tabular}


Не менш успішно General Electric використовує запатентовану технологію SPRINT (Spray inter cooling), що передбачає проміжне охолодження робочого тіла за рахунок упорскування диспергованої рідини між компресорами низького та високого тиску газової турбіни LM6000 PC, однією 3 найпопулярніших конверсійних газових турбін в діапазоні $40 \ldots 50 \mathrm{MB}$. Система SPRINT дозволила підвищити вихідну потужність турбіни в умовах ISO більше, ніж на $8 \%$, а при температурі навколишнього середовища $32{ }^{\circ} \mathrm{C}$ показники вийшли на $32 \%[6,9]$.

ВАТ "Невський завод" у 2000-х роках підготував перспективний проект - газотурбінний агрегат "Надія" потужністю 16 МВт. 3 метою забезпечення високої економічної ефективності, ресурсозбереження, надійності й екологічної безпеки в агрегаті використаний регенератор в основному циклі, охолодження повітря між компресорами і підігрів мережної води в утилізатоpi. Застосування даної теплової схеми дозволяє збільшити ККД агрегату до $42 \%$ [10].

Альтернативним способом упорскування води у повітряний потік ГТУ є застосування аеротермопресора (рис. 1). Апарат відноситься до типу струминних апаратів і складається 3 наступних основних елементів: 1) сопло (призначене для розгону повітряного потоку до швидкості близької швидкості звуку); 2) форсунка (призначена для упорскування води в потік); 3) робоча камера (де здійснюється процес термогазодинамічної компресіі); 4) дифузор (призначений для вирівнювання та зменшення швидкості і збільшення тиску потоку).

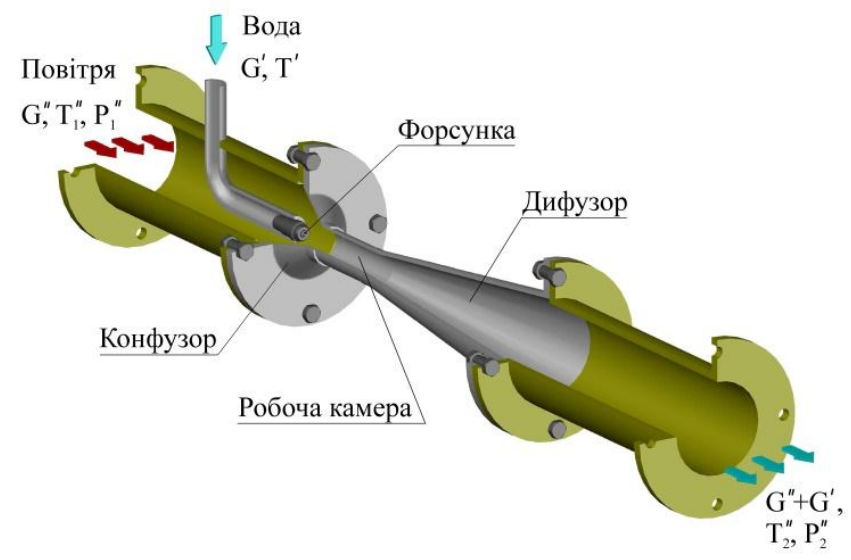

Рисунок 1 - 3D модель аеротермопресора:

$P$ - тиск; $T^{\prime}, T^{\prime \prime}$ - температура рідини і повітря;

$G^{\prime}, G^{\prime \prime}$ - витрата рідини на упорскування та повітря

Цикл ГТУ із застосуванням аеротермопресора показано на (рис. 2). Встановлення аеротермопресора пропонується між ступенями компресорів ГТУ (рис. 3).

Основні процеси циклу наступні: 1-2 - політропне стиснення в компресорі низького тиску (КНТ); 2-2 атп контактне охолодження в аеротермопресорі (АТП) із підвищенням тиску повітря (термогазодинамічна компресія); $2_{\text {атп }} 3_{\text {атп }}-$ політропне стиснення в компресорі високого тиску (КВТ); $3_{\text {атп }} 4_{\text {атп }}-$ згоряння палива в камері згоряння (КЗ) при практично постійному тиску; $4_{\text {атп }}-5$ - політропне розширення газу в турбіні високого тиску (ТВТ); 5-6 - політропне розширення газу в турбіні низького тиску (ТНТ); 6-7 - політропне розширення газу в силовій турбіні (CТ); 7-1 - умовний процес, що замикає цикл і характеризує охолодження газу в навколишньому середовищі.

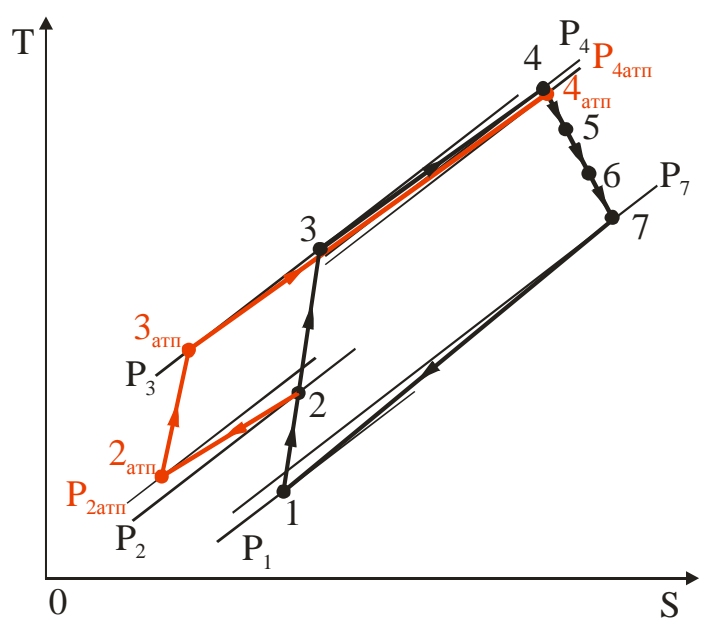

Рисунок 2 - Цикл ГТУ із застосуванням аеротермопресора для контактного охолодження повітря між ступенями компресорів

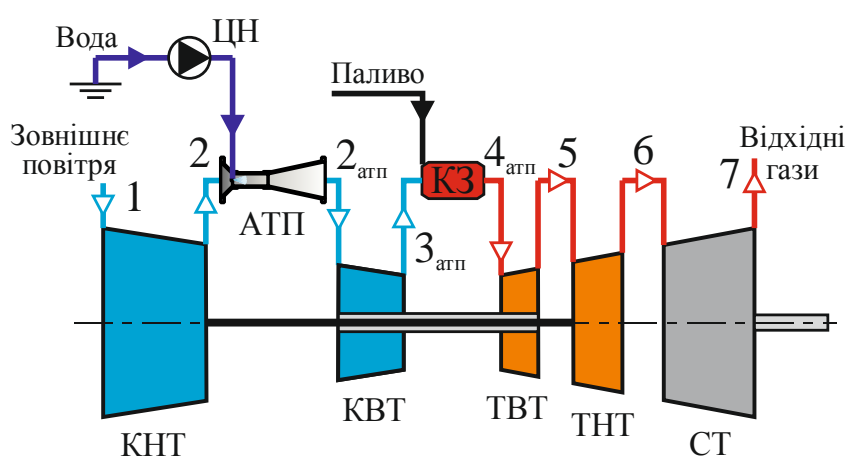

Рисунок 3 - Схема ГТУ із застосуванням проміжного охолодження циклового повітря аеротермопресором

Процеси 1-2 і 2-3 є процесами політропного стиснення повітря в КВТ і КНТ для схеми без АТП. Як видно, проміжне охолодження дозволяє збільшити ККД у порівнянні з простим циклом ГТУ (1-2-3-4-5-6-7), адже площа фігури, що характеризує корисну роботу циклу $\mathrm{S}_{\text {атп }}$ (цикл 3 АТП - $1_{\text {атп }}-2_{\text {атп }}-3_{\text {атп }}-4_{\text {атп }}-5-6-7$ ) більше $S_{\text {гту }}$ (простий цикл - 1-2-3-4-5-6-7). При цьому процес контактного охолодження в АТП проходить із деяким збільшенням тиску повітря $\mathrm{P}_{2}$, що робить такий спосіб більш ефективним (збільшення тиску повітря в АТП дозволяє додатково зменшити роботу стиснення в компресорах ГТУ), ніж простий контактний спосіб проміжного охолодження форсунками або в поверхневому повітроохолоджувачі, де охолодження повітря супроводжується напроти - втратами тиску (аеродинамічним опором).

При аналізі циклів ГТУ було використано відомі методики розрахунку циклів ГТУ [11], а також розрахунку процесу термогазодинамічної компресії $[4,12]$, на основі яких розроблено відповідний програмний комплекс. Розрахунок циклів ГТУ проводився для ступенів підвищення тиску $\pi_{\mathrm{\kappa}}=10-45$ і для повітря при парамет- 
pax, що відповідають ISO: $\mathrm{t}_{\text {нп }}=15^{\circ} \mathrm{C}, \varphi_{\text {нп }}=30 \%$, при цьому в схемах замість охолоджувача повітря (поверхневого або контактного із форсуночним упорскуванням) запропоновано встановити аеротермопресор.

Застосування аеротермопресора дозволяє знизити температуру циклового повітря між ступенями компресорів від $\mathrm{t}_{\text {аатп }}=100-180{ }^{\circ} \mathrm{C}$ до $\mathrm{t}_{\text {2атп }}=50-70{ }^{\circ} \mathrm{C}$, тобто на $\Delta \mathrm{t}_{\text {атп }}=50-110^{\circ} \mathrm{C}$ (рис. 4). Таке зниження температури в умовах термогазодинамічної компресії дає змогу підвищити тиск на $\Delta \mathrm{P}_{\text {атп }}=2-28$ кПа, тобто на 2-9\% (рис. 5). При цьому найбільший ефект підвищення тиску має місце для LMS 100. Контактне охолодження повітря аеротермопресором дозволяє зменшити роботу на стиснення компресора на 2,5-3,0 \%.

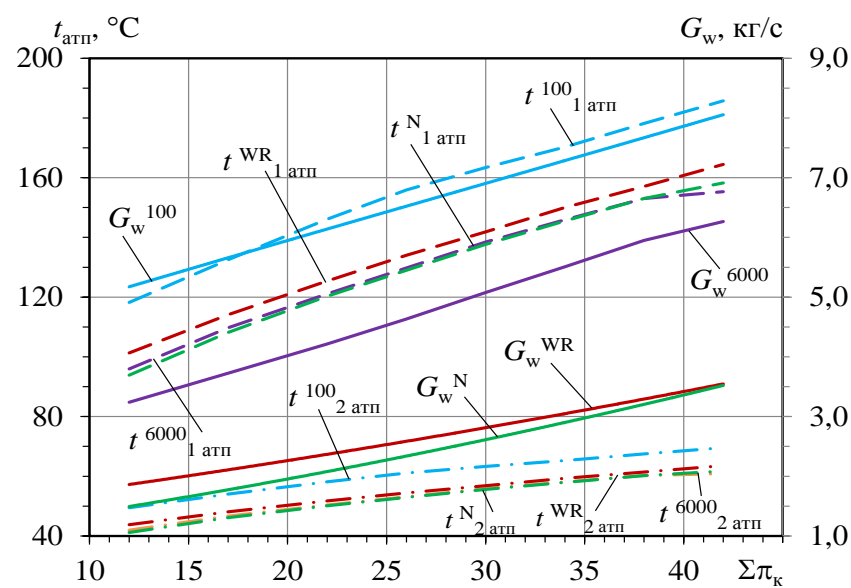

Рисунок 4 - Залежності температур на вході ( $\left.t_{1 \text { атп }}\right)$ ma на виході (t аеротермопресорі $\left(G_{\mathrm{w}}\right)$ від загального ступеня підвищення тиску компресора $\Sigma \pi_{\mathrm{K}}$

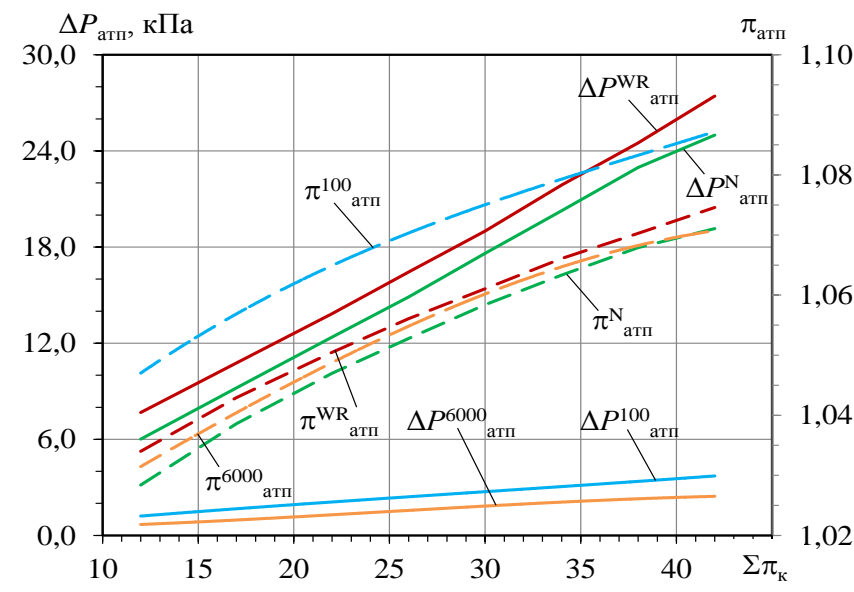

Рисунок 5 - Залежності підвищення тиску в аеротермопресорі $\left(\Delta P_{\text {атп }}\right)$, ступеня стиснення в аеротермопреcopi $\left(\pi_{\mathrm{aпп}}\right)$ від загального ступеня підвищення тиску компресора $\Sigma \pi_{\mathrm{K}}$

Витрата води для упорскування в аеротермопресорі складає для всіх установок в середньому $\mathrm{G}_{\mathrm{w}}=2-8$ кг $/ \mathrm{c}$ (2-5\%). Вода, що упорскується, після випаровування являє собою додаткове робоче тіло, збільшення якого дає в свою чергу можливість підвищити питому потужність ГТУ (рис. 6). Таке підвищення складає в залежності від схемного рішення ГТУ $\bar{N}_{\mathrm{S}}=20-50$ кВТ/(кг/с)
(3-10 \%). Найбільший вплив від застосування аеротермопресора має ГТУ марки LMS 100 в базовій схемі якої застосовано лише поверхневий проміжний охолоджувач повітря без регенератора.

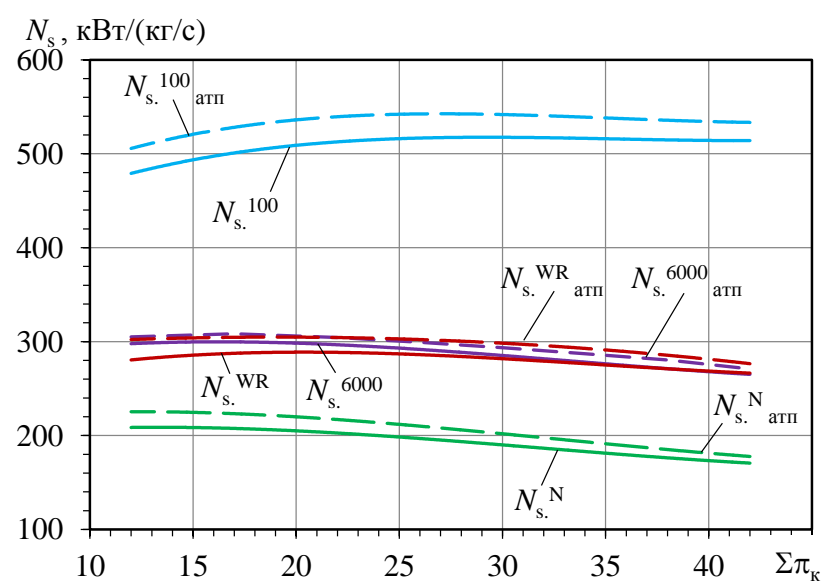

Рисунок 6 - Залежності питомої потужності ГТУ ( $\left.\bar{N}_{\mathrm{s}}\right)$ від загального ступеня підвищення тиску компресора $\Sigma \pi_{\mathrm{K}}$ :

$$
\begin{aligned}
& \text { - базова схема ГТУ без АТП; } \\
& \hline \mathbf{-}-\mathbf{-}-\text { із застосуванням АТП }
\end{aligned}
$$

Зменшення роботи компресора та одночасне збільшення кількості робочого тіла в циклі дозволяє підвищити ККД ГТУ на $\Delta \eta_{\mathrm{e}}=0,02-0,04(2-4 \%)$ в порівнянні із базовим варіантом (рис. 7). При цьому питома витрата палива зменшиться на $\Delta \mathrm{g}_{\mathrm{e}}=10-30$ г/(кВт·год). Слід зазначити, що характер зміни $\eta_{\mathrm{e}} \mathrm{i} \mathrm{g}_{\mathrm{e}}$ в залежності від ступеня підвищення тиску $\pi_{\mathrm{\kappa}}$ різний, що пов'язано із особливістю базових схем ГТУ (в схемі LMS 100 i LM6000-PC SPRINT присутнє тільки проміжне охолодження, а в схемах WR-21 і "Надія" - проміжне охолодження і регенерація теплоти).

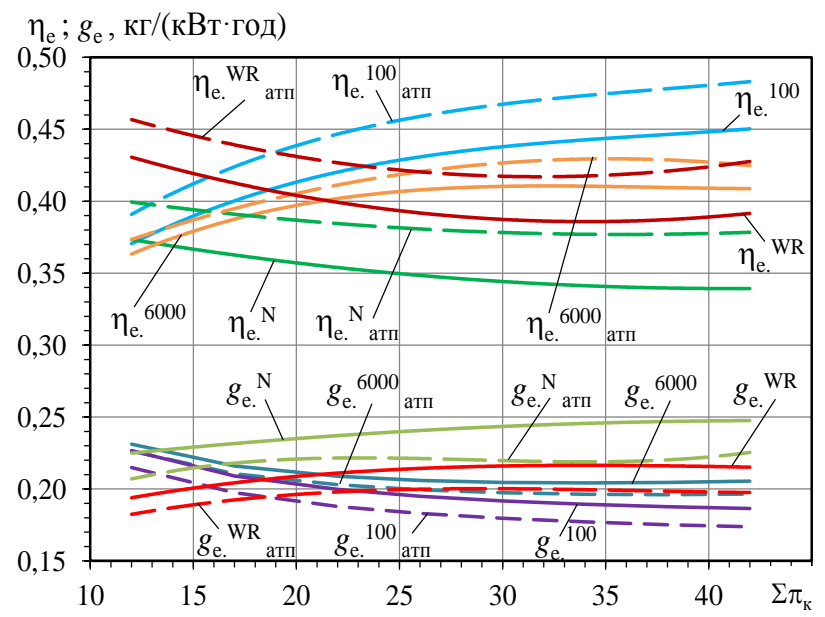

Рисунок 7 - Залежності ККД ( $\left.\eta_{\mathrm{e}}\right)$ ичиклів ГТУ та питомої витрати палива $\left(g_{\mathrm{e}}\right)$ від загального ступеня підвищення тиску компресора $\Sigma \pi_{\mathrm{K}}$ :

- - базова схема ГТУ без АТП;

- - - - iз застосуванням АТП

WR - WR-21 фipмu Rolls Royce; 100 - LMS100 фірми General Electric; 6000 - LM6000 PC фipми General Electric; N-Надія, Невський завод 
Кількість води, що упорскується в аеротермопреcop може перевищувати значення, яке необхідне для випаровування в робочій камері (до 10-15 \% відносно кількості повітря). Таке рішення дозволить забезпечити випаровування при стисненні в компресорі високого тиску i, як наслідок, наблизити процес до ізотермічного iз найменшою роботою на стиснення, тобто застосування аеротермопресора може бути альтернативним відносно традиційного контактного охолодження циклового повітря при упорскуванні форсунками.

\section{Висновки}

1. Проаналізовано ефективність застосування аеротермопресора в схемах ГТУ для контактного охолодження циклового повітря. Виявлено, що аеротермопресор дозволяє: підвищити тиск циклового повітря між ступенями компресора на $\Delta \mathrm{P}_{\text {атп }}=2-9 \%$, а від так, зменшити роботу на стиснення в ступенях компресора; збільшити кількість робочого тіла в циклі на $\Delta \mathrm{G}_{\mathrm{w}}=2-5 \%, \mathrm{i}$, як наслідок, збільшити питому потужність на $\Delta \bar{N}_{\mathrm{S}}=3-10 \%$ і ККД на $\Delta \eta_{\mathrm{e}}=2-4 \%$.

2. Аеротермопресор забезпечує ефективне дрібно-дисперсне розпилення рідини, а звідси, більш ефективне ізотермування процесу в компресорі високого тиску. При цьому додаткова кількість води, що упорскується, може складати до 10-15\% відносно витрати циклового повітря.

\section{Література}

1. Jonsson, M., Yan, J. Humidified gas turbines - a review of proposed and implemented cycles [Text] / M. Jonsson, J. Yan. // Energy. - 2005. - №30. - P. 1013 1078 .

2. Thank-God, I., Dabbashi, S., Bosak, D., Sampath S., Di Lorenzo, G., Pilidis, P. Life cycle evaluation of an intercooled gas turbine plant used in conjunction with renewable energy [Text] / I. Thank-God, S. Dabbashi, D. Bosak, S. Sampath, G. Di Lorenzo, P. Pilidis. // Propulsion and Power Research. - 2016. - Vol. 5, No. 3. - P. 184193.

3. Razzaq, W. H. A. Parametric Performance of Gas Turbine Power Plant with Effect Intercooler [Text] /
W. H. A. Razzaq. // Modern Applied Science. - 2011. Vol. 5, No. 3. - P. 173-184.

4. Shapiro, A. H., Wadleigh, K. R. Gavril, B. D., Fowi, A. A. The aerothermopressor - a device for improving the performance of a gas-turbine power plant [Text] / A. H. Shapiro, K. R. Wadleigh, B. D. Gavril A. A. Fowi. // Proceedings of the Trans. ASME. - 1956. Vol. 78, No. 7. - P.617-653.

5. Konovalov, D., Kobalava, H. Intercooling of gas turbine plants by using the aerothermopressor [Text] / D. Konovalov, H. Kobalava. // Proceedings of the X Minsk International Seminar "Heat Pipes, Heat Pumps, Refrigerators, Power Sources", Minsk, Belarus. - 2018. - pp. 269 276.

6. Bhargava, R. K., Bianchi, M., Peretto, A., Spina, P. R. A feasibility study of existing gas turbines for recuperated, intercooled and reheat cycle [Text] / R. K. Bhargava, M. Bianchi, A. Peretto, P. R. Spina // Proceedings of ASME TURBO EXPO 2002, Amsterdam, The Netherlands - 2002. - 18 p.

7. Colin, R. The WR-21 Intercooled Recuperated Gas Turbine Engine - Integration Into Future Warships [Text] / R. Colin. // Proceedings of the International Gas Turbine Congress, Tokyo. -2003 . $-6 \mathrm{p}$.

8. Reale, M. J. New High Efficiency Simple Cycle Gas Turbine - GE's LMS100 [Text] / M. J. Reale // GE Energy $-2004 .-15$ p.

9. Badeer G. H. GE Aeroderivative Gas Turbines - Design and Operating Features [Text] / G. H. Badeer // GE Power Systems, GER-3695E (10/00) - 20 p.

10. Романовський, Г.Ф. Сербін, С.І., Патлайчук, В.М. Сучасні газотурбінні агрегати. Том 1. [Текст] / Г.Ф. Романовський, C.I. Сербін, В.М. Патлайчук. - Миколаїв: НУК, 2005. - 344 с.

11. Романовський, Г. Ф., Ващиленко, М. В., Сербін, С. I. Теоретичні основи проектування суднових газотурбінних агрегатів [Текст] / Г.Ф. Романовський, Ващиленко, С.I. Сербін. - Миколаїв: УДМТУ, 2003. $304 \mathrm{c}$.

12. Вулис, Л.А. Термодинамика газових потоков [Текст] / Л.А. Вулис. - Москва, Ленинград: Госэнергоиздат, 1950. - 304 с.

Отримана в редакції 08.08.2018, прийнята до друку 04.09.2018

\title{
Contact air cooling by using the aerothermopressor in the gas turbine plant cycle
}

\author{
Dmytro Konovalov, Halina Kobalava
}

Admiral Makarov National University of Shipbuilding (Kherson branch), Ushakov Avenue, 44, Kherson, 73003, Ukraine

The analysis of the existing gas turbine plants (GTP) by using air intercooling from various manufacturers has been carried out, the main technical characteristics and basic parameters of operation of these GTP have been determined. Among the considered technologies for intercooling of cyclic air in gas turbine plants there are data from such wellknown manufacturers as Rolls-Royce, General Electric and Nevsky Plant. The main ways of implementing intercooling of cyclic air GTP have been considered, namely, cooling in the surface heat exchanger and contact cooling with injected water. An aerothermopressor apparatus used can be a promising way of moistening the working environment of a gas turbine. The aerothermopressor work is based on the process of thermogasdynamic compression (thermopression). 


\begin{abstract}
A feature of this process is an increase in pressure, as a result of the instantaneous evaporation of the liquid injected into the air flow, which is accelerated to speed near the sound. In this case, heat is removed from the air flow to evaporate water, as a result of which air temperature is decreased. A comparative analysis of the existing and aerothermopressor technologies for air intercooling of GTP has been carried out. The aerothermopressor provides more effective liquid spraying and, hence, more effective isothermal compression process in the high pressure compressor is done. The proposed cooling technology makes it possible using low-potential heat of secondary energy resources of gas turbine plants (heat of cyclic air). It has been revealed that the aerothermopressor allows to increase the pressure of the cyclic air between the compressors by 2-9\%, which leads decreasing compression work in compressor steps, and water injection leads increasing the number of working fluid in the cycle by 2-5\%, and, as a result, the power is increased by $3-10 \%$ and the GTP efficiency is increased by 2-4\%. The additional amount of injected water can be up to 10-15\% relative to the cyclic air consumption.
\end{abstract}

Keywords: Aerothermopressor, Gas Turbine Plants, Intercooling, Specific Fuel Consumption

\section{References}

1. Jonsson, M., Yan, J. 2005. Humidified gas turbines - a review of proposed and implemented cycles. Energy. 30, pp. 1013-1078.

DOI: https://doi:10.1016/j.energy.2004.08.005

2. Thank-God, I., Dabbashi, S., Bosak, D., Sampath S., Di Lorenzo, G., Pilidis, P. 2016. Life cycle evaluation of an intercooled gas turbine plant used in conjunction with renewable energy. Propulsion and Power Research. 5(3). pp. 184-193.

DOI: https://doi.org/10.1016/j.jppr.2016.07.005

3. Razzaq, W. H. A. 2011. Parametric Performance of Gas Turbine Power Plant with Effect Intercooler. Modern Applied Science. 5(3) pp. 173-184.

DOI: https://doi:10.5539/mas.v5n3p173

4. Shapiro, A. H., Wadleigh, K. R. Gavril, B. D., Fowi, A. A. 1956. The aerothermopressor - a device for improving the performance of a gas-turbine power plant. ed. Proceedings of the Trans. ASME. 78(7), pp. 617-653.

5. Konovalov, D., Kobalava, H. 2018. Intercooling of gas turbine plants by using the aerothermopressor. Ed. Proceedings of the X Minsk International Seminar "Heat Pipes, Heat Pumps, Refrigerators, Power Sources", Minsk, Belarus, 2018, pp. 269-276

https://www.researchgate.net/publication/327670062

6. Bhargava, R. K., Bianchi, M., Peretto, A., Spina, P. R. 2002. A feasibility study of existing gas turbines for recuperated, intercooled and reheat cycle. Ed. Procee- dings of ASME TURBO EXPO 2002, Amsterdam, The Netherlands, 2002, $18 \mathrm{p}$.

https://www.researchgate.net/publication/245353534

7. Colin, R. 2003. The WR-21 Intercooled Recuperated Gas Turbine Engine - Integration Into Future Warships. Ed. Proceedings of the International Gas Turbine Congress, Tokyo, 2003, $6 \mathrm{p}$.

https://nippon.zaidan.info/seikabutsu/2003/00916/pdf/igtc2 003tokyo_os203.pdf

8. Reale, M. J. 2004. New High Efficiency Simple Cycle Gas Turbine - GE's LMS100. GE Energy, 15 p.

https://www.ge.com/content/dam/gepower-

pgdp/global/en_US/documents/technical/ger/ger-4222anew-high-efficiency-simple-cycle-gas-turbine-lms100.pdf

9. Badeer G. H. GE Aeroderivative Gas Turbines - Design and Operating Features. GE Power Systems, GER3695E (10/00), 20 p.

http://www.industrialgeneratorsforsale.com/wpcontent/uploads/2017/08/ge-LM6000-LM2500-aero-gasturbine-design-features.pdf

10. Romanov``ky’j, G. F. Serbin, S.I., Patlajchuk, V.M. 2005. Suchasni gazoturbinni agregaty. My`kolayiv: NUK. (in Ukrainian)

11. Romanovs`ky’j, G. F., Vashhy`lenko, M. V., Serbin, S. I. 2003. Teorety`chni osnovy` proektuvannya sudnovy`x gazoturbinny`x agregativ. My`kolayiv: UDMTU. (in Ukrainian)

12. Vulis, L.A. 1950. Termodinamika gazovih potokov. Moskva, Leningrad: Gosjenergoizdat (in Russian) 